\title{
Decline as a Disease Category: Is It Helpful?
}

\author{
M. E. Ostry, R. C. Venette, and J. Juzwik
}

United States Department of Agriculture, Forest Service, Northern Research Station, St. Paul, MN 55108. Accepted for publication 9 December 2010.

\begin{abstract}
Ostry, M. E., Venette, R. C., and Juzwik, J. 2011. Decline as a disease category: Is it helpful? Phytopathology 101:404-409.

Many, but not all, forest pathologists use "decline" to describe forest tree diseases of complex etiology. We contend that this distinction from abiotic or biotic diseases is completely arbitrary, has caused undue confusion, and provides no practical insights for forest managers. All diseases are complex and can be characterized within the conceptual framework of the disease triangle. Why do we use a simple label

origin when we need to know which damaging agents are present, whether the environment is conducive for disease progression, and host susceptibility over time to understand the origins and management of disease? We propose that forest pathologists discontinue the use of "decline" as a distinct category of disease. Furthermore, we suggest that new diseases should be named based on the affected host, characteristic symptom, and, once known, major determinant. We believe that clearer communication in describing complex diseases is a prerequisite to finding effective management options.
\end{abstract} ("decline") to describe disease situations of complex abiotic and biotic
A tree is diseased when normal, physiological functions are altered by abiotic factors, biotic agents, or combinations thereof $(50,77)$. Historically, forest pathologists have categorized diseases as biotic, abiotic, and decline (50). The decline category usually includes diseases of complex etiology. In contrast, general plant pathology texts (1) list only two categories: biotic (infectious) and abiotic (noninfectious).

Diseased trees occasionally exhibit a suite of symptoms that are indicative of poor plant vigor but are not diagnostic for a single causal factor or agent $(74,82)$. Such symptoms include slowed growth, thin crowns, discolored leaves, misshapen or smallerthan-normal leaves, inadequate storage reserves, abnormally high sexual reproduction, branch or stem dieback, and, perhaps, premature mortality. Trees with one or more of these symptoms are often said to have a "dieback" or "decline" disease, regardless of whether the etiology is known or not $(33,56,78)$. Many dieback diseases have been placed in the decline category (e.g., ash [Fraxinus spp.] dieback, birch [Betula spp.] dieback, and maple [Acer spp.] dieback). Thus, forest tree diseases of presumably complex etiology have become a specific disease category $(34,35,56,72)$.

Many definitions suggest subtle distinctions between decline and dieback but these distinctions have become muddled. The American Heritage Dictionary of the English Language (58) defines "decline" as "the process or result of declining; especially, gradual deterioration" and "dieback" as "the gradual dying of plant shoots, starting at the tips, as a result of various diseases or climatic conditions." The Dictionary of Forestry (24) defines decline as "the decrease in trees, shrubs, and herbs, or forest health and vigor, caused by one or more biotic or abiotic factors" and dieback as "the progressive dying from the extremity of any part of a plant—note dieback may or may not result in the death of the entire plant." The Glossary of Plant-Pathological Terms (70) describes decline as "reduced vigor of perennial plantings as

Corresponding author: M. E. Ostry; E-mail address: mostry@fs.fed.us

doi:10.1094/PHYTO-06-10-0153

This article is in the public domain and not copyrightable. It may be freely reprinted with customary crediting of the source. The American Phytopathological Society, 2011. a result of chronic symptoms of disease; the gradual reduction in health and vigor of a plant or planting that is in the process of slowly dying" and dieback as "progressive death of shoots, branches, or roots generally starting at the tip. Dieback may be due to cankers, stem or root rots, insect borers, nematodes, winter injury, deficiency or excess of moisture or nutrients, some other factor, or a stress complex." Shigo (69) considered dieback to be "the reduction in the dynamic mass of a tree as twigs and branches die and are walled off by protection boundaries" and decline to be the "general loss of vitality over the entire tree either caused by a systemic disease or a series of events that disrupt essential life processes." Sinclair and Lyon (74) describe decline as a progressive loss of vitality and further state that decline is a natural part of the life cycle of all higher organisms. Thus, we conclude that dieback and decline are not synonymous. We view dieback as a symptom of disease. Furthermore, we believe that decline is an ambiguous category and a term that is not useful in describing a disease.

Although episodes of forest and tree declines have been reported numerous times for $>100$ years (53), usage of the term has increased since the 1980s. At that time in Europe and North America, increases in reports and concern about unprecedented crown thinning and tree mortality described as the "Waldsterben syndrome" or forest death were initially attributed to acid precipitation and air pollution $(29,41,45,67,75)$. The name "Waldsterben syndrome" gave the impression that entire forests were dying but this description was technically incorrect because what was being described were symptoms of localized tree species not entire forests of multiple tree species (75). These descriptions gave the misleading impression that all declines resulted in tree death. Both errors have added to the confusion over what tree or forest decline describes.

Not all forest pathologists agree that decline is a distinct category of disease (50). In this letter, we critically review models of tree decline diseases. Specifically, we address the question, "Is decline a distinct category of disease?" We argue that this is not the case, and contend that the disease triangle (16) adequately accounts for disease complexes described as declines. We agree with Skelly (75) that a catch-all term such as decline to describe unhealthy trees is nonetiologically discriminant. This letter is 
motivated by our deepening concern that recent occurrences of widespread tree species dieback and mortality are too quickly being categorized as decline diseases.

Conceptual models of decline disease. Several authors have refined the decline disease concept (53). Most refinements kept many of Sinclair's (72) fundamental ideas about "predisposing factors," recognized by Ward (82), that weaken a tree and make it less resilient to stress; "inciting factors" that are directly responsible for the initial decline symptoms; and "contributing factors" that ultimately cause tree death. Houston (35) compared numerous species dieback and declines and proposed a common etiology which he later described in a host-stress-saprogen model (36). The model explained how trees stressed by weather or defoliation were invaded by a complex of secondary, opportunistic or saprogenic organisms, not normally able to invade unstressed trees. Manion (50) proposed a similar idea but placed more emphasis on the temporal sequence of factors and their interaction; his conceptual model was illustrated through a decline disease spiral that depicted the series of events that culminated in tree death. In contrast, Mueller-Dombois and others (61) described the theory that some declines are more reflective of tree population dynamics than the consequence of pathogens.

Sinclair and Hudler (73) used four models to explain the causes of tree decline: (i) decline caused primarily by continual stress by one factor; (ii) decline caused by drastic injury plus secondary stress; (iii) decline caused by interchangeable predisposing, inciting, and contributing factors; and (iv) cohort senescence, where normal decline follows forest succession. These models for decline diseases are similar, all attempting to illustrate the roles of multiple interacting factors. However, have these concepts improved our understanding of complex disease etiologies compared with the disease triangle that already accounts for these interactions (Fig. 1)?

Critique of decline as a descriptive disease category. Although conceptual models of decline can be intellectually stimulating, they have proven difficult to test empirically and are generally unsatisfactory from an applied perspective. We provide six arguments against using decline as a disease category.

Many "simple" diseases have decline symptoms. Many wellknown diseases thought to be caused by a single damaging agent result in dieback and progressive reduction in the vigor and growth rate of affected trees characteristic of what have been described as declines. Branch dieback is a characteristic symptom of oak wilt in white oak (Quercus section Quercus) caused by Ceratocystis fagacearum (40). Thinning crowns and discolored foliage are associated with annosum root rot caused by Heterobasidion irregulare ( $=$ H. annosum) (85). More generally, Dukes and others (13) and Spaulding (77) categorized many diseases caused by well-known native and introduced insect pests and pathogens as tree declines. Thus, trees with dieback or decline symptoms in tree crowns are not restricted to maladies described as decline diseases.

All diseases have a complex etiology, not just decline diseases. The plant pathology literature is replete with descriptions of chronic and acute, biotic and abiotic diseases, all exhibiting various levels of complexity. For example, it has been demonstrated that the occurrence of Hypoxylon canker of aspen (Populus tremuloides) is influenced by many interacting factors (64). Wounds made by various insects into the xylem of branches, water stress, stand density, and clonal variation in canker resistance are just a few of the factors affecting the incidence and severity of the disease across the range of aspen. White pine blister rust, caused by Cronartium ribicola, has an extremely complex biology. Disease incidence is determined by the presence of the telial alternate hosts, critical microclimate for spore dispersal and infection, host resistance, and pathogen virulence (20). Despite this complexity, neither Hypoxylon canker of aspen nor white pine blister rust has been considered to be a decline disease.

Decline diseases have often been separated from single-agent diseases by the multiple interacting factors involved; however, as the examples above demonstrate, forest tree diseases result from numerous biotic and abiotic factors. Jones (38) urged plant

\section{Conducive Environment}

inciting determinants

[e.g. weather, water, nutrient extremes, defoliation]

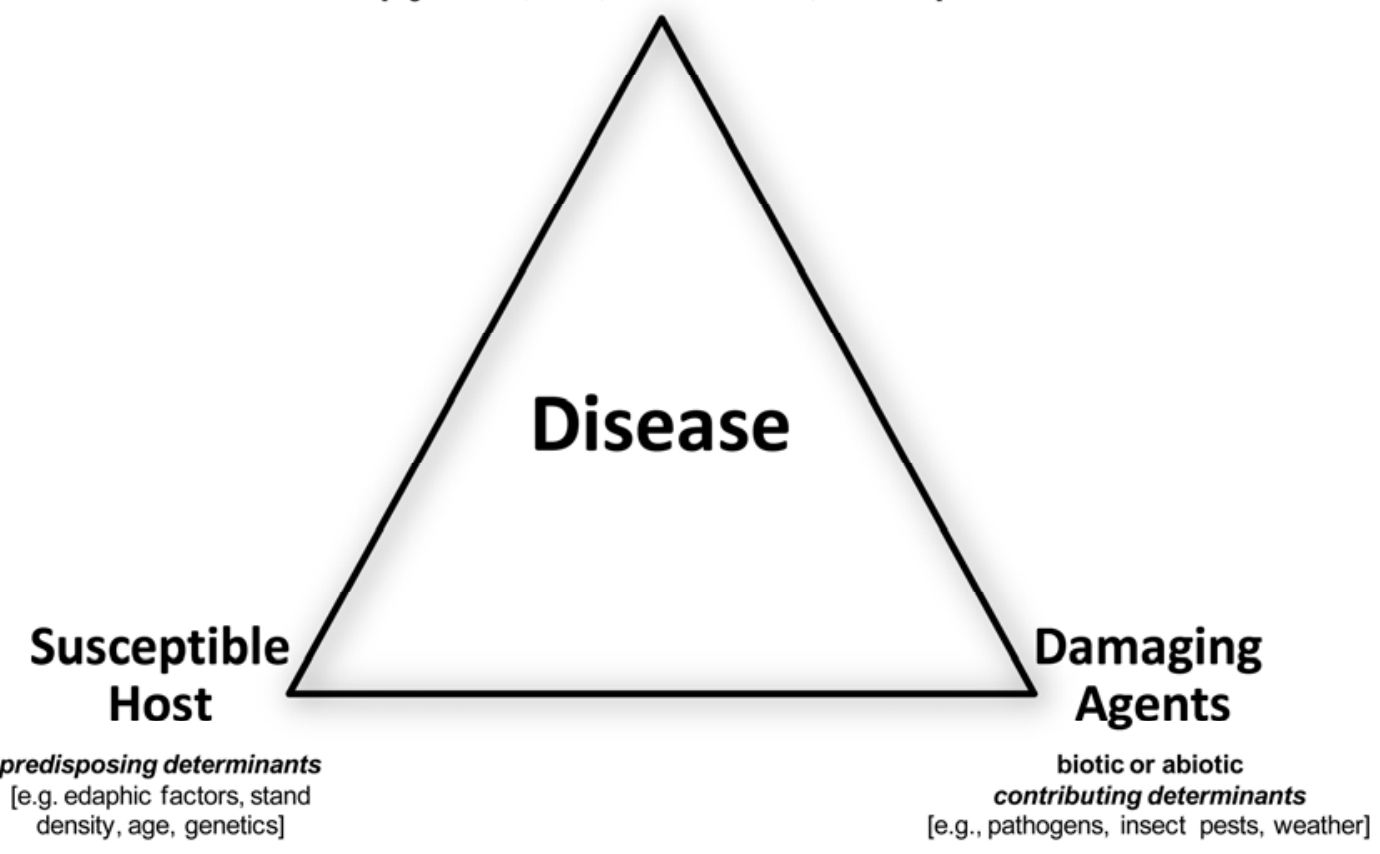

Fig. 1. Modified disease triangle, reflecting the concepts of contributing, inciting, and predisposing determinants typically mentioned in discussions of decline diseases. 
pathologists to pay more attention to the disease and the relation of environment to disease inception rather than to a single parasite in order to explain disease occurrence. We agree with Colhoun $(11,12)$, who stressed the need to study the interactions of multiple environmental factors on plant disease development, not just one factor at a time.

The disease triangle adequately describes the expression of decline symptoms. The disease triangle is a fundamental conceptual model in plant pathology and illustrates how disease results from the interaction of the host, the pathogen, and the environment. No one factor can be considered more important than another (62). The disease triangle can also incorporate concepts traditionally applied to tree declines. Specifically, predisposing factors alter the susceptibility of the host; inciting factors include the environmental conditions needed for infection, and contributing factors include the pathogens or other damaging agents. For example, mounting evidence suggests that oak decline in the Ozark Mountains of Missouri and Arkansas can be attributed to the confluence of a damaging agent (red oak borer, Enaphalodes rufulus), susceptible hosts (especially members of the red oak section Lobatae), and a conducive environment (drought or moisture-stressed trees) $(15,23,78)$.

Perhaps the greatest conceptual change when applying the disease triangle to declines is the idea that the disease may reflect the interaction of two or more damaging agents. Beech decline (33), now known as beech bark disease, is provided as one example. The damaging agents necessary for disease expression are the beech scale (Cryptococcus fagisuga) and one or more Neonectria spp. (10). Recent research has demonstrated the importance of a host (Fagus grandifolia, in the eastern United States) that is genetically predisposed to scale attack in this pathosystem (46). At this time, however, the importance of environmental conditions in the infection process and disease development is not clear.

A decline diagnosis does not forecast the fate of a tree. The definitions of decline or dieback are inconsistent with respect to implications for tree death; not all trees with dieback have a decline disease that will result in premature mortality $(49,71)$. Slow growth, branch dieback, and branch abscission are wellknown responses of trees to stress and are physiological survival mechanisms (57). Stress changes normal patterns of photosynthate allocation in affected trees and the extent of abnormalities and amount of storage reserves influences the probability of tree survival.

Numerous surveys and reports of decline diseases offer little quantitative data on growth impacts and even less on their etiology $(3,4)$. Often, the onset and subsidence of dieback was rapid and patterns of dieback were cyclic. Evaluations of crown dieback to assess tree health may have combined recovering trees with deteriorating trees (54).

Some long-term studies highlight cases where trees that were thought to be declining did not die. In Ontario, sugar maple (Acer saccaharum) crown condition was not correlated with short-term tree death, and the relationship between crown condition and tree death differed among forest regions. These results indicated that multiple disturbances were involved in tree death and emphasized the need for long-term observations to increase prediction reliability (79). In Missouri, tree crown condition did not worsen over 14 years in $70 \%$ of red oaks (Quercus rubra) originally diagnosed with decline, and the health of approximately $50 \%$ of trees with decline seemed to improve during that period (14). Determining whether occurrences of dieback or decline disease will lead to tree death requires study of affected trees over time.

Tree decline is a normal progression in the development of forest stands. Hyink and Zedaker (37) emphasize that a thorough understanding of stand dynamics is critical to evaluate a decline. Reduced growth is not evidence of a decline disease. Expected or normal growth is a function of site quality, stand density, and age, and these factors must be evaluated. Tree ring analysis of sugar maple and red spruce (Picea rubens) in Vermont revealed shortlived and persistent growth declines associated with disturbance, climate, and stand dynamics (19). Results of a study of red spruce decline provided guidance for managers to evaluate its impact (6). The authors suggested that dying canopy trees are a fundamental process and that knowledge of the existing disturbance regime and forest community organization is essential to understand the consequences in terms of stand recovery.

Franklin and others (17) discussed tree death as an arbitrary point on a continuum and that tree death is frequently a complex and gradual process, with multiple contributors of biotic and abiotic agents. Like Hyink and Zedaker (37), they also stress the importance of knowledge of the natural history of individual species and ecosystems in understanding tree death. Synchronous, stand-level dieback or cohort senescence and canopy dieback has been proposed as a natural process of forest dynamics $(51,59,60)$ and not a specific forest decline disease.

Reports of widespread dieback and mortality of aspen in the United States and Canada $(18,30,68,86)$ provide an interesting example of the potential complexity of stand dynamics and disease development. Defoliation, regional droughts, thaw-freeze events, animal damage, and a number of foliage and stem diseases have all been implicated in the phenomenon. Drought, however, has been most commonly associated (66). Guyon (22) contends that the most recent aspen mortality in western North America does not fit the decline models because aspen in all size classes was affected, and heavy grazing and weather can explain the death of aspen clones. He suggests that perhaps the loss of aspen and increase in the conifer component is actually a restoration of normal landscape patterns in that region.

In other cases illustrating the complexity of stand dynamics and disease development, stand structure (density, age, and composition) combined with natural and human disturbance in sugar maple stands have been associated with declines in Wisconsin, Vermont, and New York $(32,84)$. Stand density and adverse climatic conditions were shown to be correlated with sugar maple decline in New York (7) and the authors suggested that the decline may be a natural process to regulate stand density, leading to stand recovery. Manion and Griffin (52) emphasize the need for baseline data on tree species health and provide evidence to support the hypothesis that predictable mortality caused by the interactions of insects and diseases together with stand dynamics is essential for maintaining forest health. We maintain that changes in tree growth and the incidence of tree mortality need to be evaluated in the context of stand development.

A decline disease diagnosis does not improve tree management. Forest pathologists and entomologists are expected to diagnose and explain tree damage and mortality in terms of the causal damaging agent and recommend management solutions. Thus, most tree declines have been dilemmas for managers because, in many cases, no single causal agent was identified.

From a practical standpoint, diagnosing a tree with decline disease can confuse the causes of tree disease with its consequences. Westing (83) pointed out that the symptoms of what, at that time, was being called sugar maple decline were the same that sugar maples and other hardwoods display "when sick or dying from most known pathological or adverse environmental conditions, or when approaching the end of their lifespans." Hepting (28) placed sugar maple disorders variously called maple blight, maple decline, and maple dieback into five categories, each with a number of different interacting causal agents, with the contention that accurate diagnosis of disease should lead to improved tree management. We believe that, in the absence of obvious causal agents of a malady, communicating the most likely factors involved in a disease will provide managers a better basis for making decisions than providing a decline diagnosis. 


\section{RECOMMENDATIONS}

Discontinue the use of decline as a specific disease category. Clear communication requires the use of precise terminology (8), especially in the case of a specialized scientific field such as forest pathology. Decline models illustrate the complex nature of tree diseases. However, to date, there is still no widespread agreement or common understanding on what is meant by the terms dieback and decline as they relate to forest tree health. Nor is there agreement on the cause, impact, or whether the condition is natural and should be expected.

We do not believe there is a need for a decline disease category. By definition, disease, whether resulting from biotic, including insects (63), or abiotic determinants, is a condition resulting from a complex of factors and is explained by the disease triangle concept. We agree with Kandler (41) that, after study, what initially resembled a complex decline disease may, instead, be a complex of diseases. Determining the underlying causes of complex tree diseases can only be done with thorough, carefully designed research methods.

Increase efforts to detect major disease determinants. Bateman (5) contended that effort is too often focused on elucidating a single cause for a phenomenon rather than on the complex of determining elements. Link (48) stated that a "thoroughgoing" etiology of disease must deal with causal complexities or the antecedents of the phenomenon. Whether a disease has a simple or complex etiology is largely a matter of opinion but, in all diseases, plant genotype and biotic and abiotic environmental factors and the interactions between them are key elements (21).

Spaulding (76), through careful field investigations, showed that the white pine blight that was being reported was actually a complex of several diseases involving numerous fungi, insects, weather events, and suppression from competition among trees for light. Wallace (81) reviewed and supported the thesis that the phenomenon of a specific cause of disease is rare in nature. Further, similar to others $(17,37)$, he considered that diseases of complex etiologies are as much an ecological as a pathological problem and suggested the synoptic approach using multi-regression equations to elucidate the major determinants to develop a diagnosis. Similar disease symptoms can develop across a range of locations but may be the result of very different disease determinants. Inherent with using this approach with forest tree declines is the obvious time and funding requirements when working with wild trees across large geographical areas and where little detailed empirical evidence exists.

Many authors have suggested that examining disease patterns across geographical areas (landscape pathology) (31) and using regional climate models can help explain the dynamic relationship between climate and tree mortality (55). Hennon (25) contends that widespread tree species declines can reflect the effects of climate change. In this hypothesis, trees that have grown in previous climates become maladapted as the climate changes and this can result in forest composition changes.

Based on a literature review of tree declines in the eastern United States and their relationships to atmospheric pollutants, Millers and others (56) found that most declines could be attributed to droughts, defoliation, and other biotic and abiotic stress agents but not atmospheric pollution. Kolb and McCormick (47) reported that the decline in growth of sugar maple in Pennsylvania was caused by defoliation, drought, nutrient deficiency, and damage by pear thrips (Taeniothrips inconsequens). Dieback of northern hardwoods in Upper Michigan was attributed to rootlet mortality due to high water tables (42), and top-dying in yellow birch (Betula alleghaniensis) was associated with heavy seed production (44). Unless aerial surveys are followed up with sufficient investigations on the ground, primary determinants of dieback and a potential decline condition may not be resolved. Kessler (43) reported that all northern hardwoods were affected by cyclical dieback caused by several biotic and abiotic agents over a 40-year period but little tree mortality or reduced growth resulted. We contend that tree diseases are complex and many symptoms are not unique to those caused by single agents; thus, care must be exercised in diagnosing them.

Provide more descriptive names of tree diseases once major determinants are known. An accurate disease name that reflects what we truly know about a disease will facilitate communication, a first step toward finding better management options under current and future forest stand conditions. The naming of new tree diseases follows no formal rules, and we believe there is a recent rush to include decline in too many instances. As an alternative, we suggest that new disease names of trees include the name of the host, a major disease determinant, and a typical symptom. This approach is consistent with recommendations from The American Phytopathological Society for publication of a Plant Disease Note (2).

Once the major determinant is known, then the disease name should reflect its cause. For example, yellow-cedar mortality has been called a decline in the past. The cause has recently been attributed to root freezing damage resulting from the lack of insulating snow cover (26). We propose that this disease now be called "root freezing of yellow-cedar." Similarly, we suggest that oak decline in Missouri and Arkansas now be described as "red oak borer damage." When a major determinant is not known, we believe it would be helpful to at least use a specific symptom or type of damage in the name rather than the term decline. For instance, a recent study of what has been referred to as black ash (Fraxinus nigra) decline in Minnesota found no biotic agent to be a major determinant of tree condition (65). Branch dieback was the main symptom observed and $90 \%$ of the surveyed trees were not dead; however, many exhibited evidence of crown recovery. The frequency of dead trees and those with dieback was greatest near roads and on the wettest sites. Although the major determinants of the disease are still not known, the authors chose to refer to the disease as black ash dieback.

\section{CONCLUDING REMARKS}

More trees displaying a wide array of symptoms indicative of poor vigor are expected as a consequence of climate change $(9,30,39,80)$, a prediction made by Hepting (27) in 1963, especially in stressed species near the edge of their native ranges and in stands growing on marginal sites. We can make little progress in our understanding and management of these diseases if we diagnose them as declines without systematically investigating potential underlying causes. The predicted greater frequency of occurrence of diseases with complex etiologies will require multidisplinary teams to sort through the numerous biotic and abiotic causal factors and their interactions in order to elucidate the major determinants.

\section{LITERATURE CITED}

1. Agrios, G. N. 1988. Plant Pathology. Academic Press, Inc., San Diego, CA.

2. The American Phytopathological Society. 2011. Plant disease instructions for authors, 2011. http://apsjournals.apsnet.org/userimages/ContentEditor/ 1236780011229/pd_author_instructions.pdf.

3. Auclair, A. N. D. 2005. Patterns and general characteristics of severe forest dieback from 1950 to 1995 in the northeastern United States. Can. J. For. Res. 35:1342-1355.

4. Auclair, A. N. D., Worrest, R. C., Lachance, D., and Martin, H. C. 1992. Climatic perturbation as a general mechanism of forest dieback. Pages 3858 in: Forest Decline Concepts. P. D. Manion and D. Lachance, eds. American Phytopathological Society, St. Paul, MN.

5. Bateman, D. F. 1978. The dynamic nature of disease. Pages 53-83 in: Plant Disease: An Advanced Treatise. Vol. III. J. G. Horsfall and E. B. Cowling, eds. Academic Press, New York.

6. Battles, J. L., and Fahey, T. J. 2000. Gap dynamics following forest decline: A case study of red spruce forests. Ecol. Appl. 10:760-774. 
7. Bauce, E., and Allen, D. C. 1991. Etiology of a sugar maple decline. Can. J. For. Res. 21:686-693.

8. Boss, L., and Palely, J. E. 1995. Concepts and terminology on plant/pest relationships: Toward consensus in plant pathology and crop protection. Annu. Rev. Phytopathol. 33:69-102.

9. Brassier, C. M. 1996. Phytophthora cinnamomi and oak decline in southern Europe: Environmental constraints including climate change. Ann. For. Sci. 53:347-358.

10. Castlebury, L. A., Rossman, A. Y., and Hyten, A. S. 2006. Phylogenetic relationships of Neonectria/Cylindrocarpon on Fagus in North America. Can. J. Bot. 84:1417-1433.

11. Colhoun, J. 1973. Effects of environmental factors on plant disease. Annu. Rev. Phytopathol. 11:343-364.

12. Colhoun, J. 1979. Predisposition by the environment. Pages 75-96 in: Plant Disease: An Advanced Treatise. Vol. IV. J. G. Horsfall and E. B. Cowling, eds. Academic Press, New York.

13. Dukes, J. S., Pontius, J., Orwig, D., Garnas, J. R., Rodgers, V. L., Brazee, N., Cooke, B., Theoharides, K. A., Stange, E. E., Harrington, R., Ehrenfeld, J., Gurevitch, J., Lerdau, K., Stinson, J., Wick, R., and Ayres, M. 2009. Response of insect pests, pathogens, and invasive plant species to climate change in the forests of northeastern North America: What can we predict? Can. J. For. Res. 39:231-248.

14. Dwyer, J. P., Kabrick, J. M., and Wetteroff, J. 2007. Do improvement harvests mitigate oak decline in Missouri Ozark forests? North. J. Appl. For. 24:123-128.

15. Fierke, M. K., Kinney, D. L., Salisbury, V. B., Crook, D. J., and Stephen, F. M. 2005. Development and comparison of intensive and extensive sampling methods and preliminary within-tree population estimates of red oak borer (Coleoptera: Cerambycidae) in the Ozark Mountains of Arkansas. Environ. Entomol. 34:184-192.

16. Francl, L. J. 2001. The disease triangle: A plant pathological paradigm revisited. The Plant Health Instructor in Teaching Articles, Education Center. The Plant Health Instructor ISSN:1935-941.

17. Franklin, J. F., Shugart, H. H., and Harmon, M. E. 1987. Tree death as an ecological process. BioScience 37:550-556.

18. Frey, B. R., Lieffers, J., Hogg, E. H., and Landhäusser, S. M. 2004. Predicting landscape patterns of aspen dieback: Mechanisms and knowledge gaps. Can. J. For. Res. 34:1379-1390.

19. Gavin, D. G., Beckage, B., and Osborne, B. 2008. Forest dynamics and the growth decline of red spruce and sugar maple on Bolton Mountain, Vermont: A comparison of modeling methods. Can. J. For. Res. 38:26352649.

20. Geils, B. W., Hummer, K. E., and Hunt, R. S. 2010. White pines, Ribes, and blister rust: A review and synthesis. For. Pathol. 40:147-185.

21. Grogan, R. G. 1983. The role of genetics in etiological pathology and maintenance of plant health. Pages 95-104 in: Challenging Problems in Plant Health. T. Kommedahl and P. H. Williams, eds. The American Phytopathological Society, St. Paul, MN.

22. Guyon, J. C., II 2006. Are the changes in aspen forests in western North America a forest decline? Pages 95-101 in: Proc. 53rd West. Int. For. Dis. Work Conf. Jackson, WY. J. Guyon, J. comp. Intermountain Region, U.S. Department of Agriculture, Forest Service, Ogden, UT.

23. Haavik, L. J., Fierke, M. K., and Stephen, F. M. 2010. Factors affecting suitability of Quercus rubra as hosts for Enaphalodes rufulus (Coleoptera: Cerambycidae). Environ. Entomol. 39:520-527.

24. Helms, J. A., ed. 1998. The Dictionary of Forestry. Society of American Foresters, Bethesda, MD.

25. Hennon, P. E. 2008. Pathology without pathogens: Opportunities for forest pathologists in a changing climate. Pages 47-51 in: Proc. 55th West. Int. For. Dis. Work Conf. Sedona, AZ. M. G. McWilliams, comp. Oregon Department of Forestry, Salem.

26. Hennon, P., Amore, D. D., Wittser, D., Johnson, A., Schaberg, P., Hawley, G., Beier, C., Sink, S., and Juday, G. 2006. Climate warming, reduced snow, and freezing injury could explain the demise of yellow-cedar in southeast Alaska, USA. World Resource Rev. 18:427-450.

27. Hepting, G. H. 1963. Climate and forest diseases. Annu. Rev. Phytopathol. 1:31-50.

28. Hepting, G. H. 1971. Diseases of forest and shade trees of the United States. U.S. Dep. Agric. For. Serv. Handb. 386.

29. Hinrichsen, D. 1987. The forest decline enigma. BioScience 37:542-546.

30. Hogg, E. H., Brandt, J. P., and Michaelian, M. 2008. Impacts of a regional drought on the productivity, dieback, and biomass of western Canadian aspen forests. Can. J. For. Res. 38:1373-1384.

31. Holdenrieder, O., Pautasso, M., Weisberg, P. J., and Lonsdale, D. 2004. Tree diseases and landscape processes: The challenge of landscape pathology. Trends Ecol. Evol. 19:446-452.

32. Horsley, S. B., Long, R. P., Bailey, S. W., Hallett, R. A., and Wargo, P. M. 2002. Health of eastern North American sugar maple forests and factors affecting decline. North. J. Appl. For. 19:34-44.

33. Houston, D. R. 1981. Stress triggered tree diseases-the diebacks and declines. U. S. Dep. Agric. For. Serv. NE-INF-41-81.

34. Houston, D. R. 1986. Recognizing and managing diebacks/declines. Pages 153-166 in: Proc. Integr. Pest Manage. Symp. North. For. Madison, WI.

35. Houston, D. R. 1987. Forest tree declines of the past and present: Current understanding. Can. J. Plant Pathol. 9:349-360.

36. Houston, D. R. 1992. A host-stress-saprogen model for forest diebackdecline diseases. Pages 3-25 in: Forest Decline Concepts. P. D. Manion and D. Lachance, eds. American Phytopathological Society, St. Paul, MN.

37. Hyink, D. M., and Zedaker, S. M. 1987. Stand dynamics and the evaluation of forest decline. Tree Physiol. 3:17-26.

38. Jones, L. R. 1924. The relation of environment to disease in plants. Am. J. Bot. 10:601-609.

39. Jung, T. 2009. Beech decline in central Europe driven by the interaction between Phytophthora infections and climatic extremes. For. Pathol. 39:73-94.

40. Juzwik, J. 2000. An oak wilt primer. International Oaks 11:14-20.

41. Kandler, O. 1992. The German forest decline situation: A complex disease or a complex of diseases. Pages 59-84 in: Forest Decline Concepts. P. D. Manion and D. Lachance, eds. American Phytopathological Society, St. Paul, MN.

42. Kessler, K. J., Jr. 1965. Dieback of managed, old-growth northern hardwoods in upper Michigan 1954-1964 - a case history. Plant Dis. Rep. 49:483-486

43. Kessler, K. J., Jr. 1967. Dieback not a cause of mortality or reduction of growth or quality in Lake States northern hardwoods. J. For. 65:892-893.

44. Kessler, K. J., Jr. 1969. Top-dying of yellow birch associated with seed production. Plant Dis. Rep. 53:694-697.

45. Klein, R. M., and Perkins, T. D. 1988. Primary and secondary causes and consequences of contemporary forest decline. Bot. Rev. 54:1-43.

46. Koch, J. L., Carey, D. W., Mason, M. E., and Nelson, C. D. 2010. Assessment of beech scale resistance in full- and half-sibling American beech families. Can. J. For. Res. 40:265-272.

47. Kolb, T. E., and McCormick, L. H. 1993. Etiology of sugar maple decline in four Pennsylvania stands. Can. J. For. Res. 23:2395-2402.

48. Link, G. K. K. 1933. Etiological phytopathology. Phytopathology 23:843862 .

49. Manion, P. 1988. Hardwood forest declines-concepts and management. Pages 127-130 in: Proc. Soc. Am. For. Natl. Conv. Rochester, NY.

50. Manion, P. D. 1991. Tree Disease Concepts. Prentice-Hall, Inc., Englewood Cliffs, NJ.

51. Manion, P. D. 2003. Evolution of concepts in forest pathology. Phytopathology 93:1052-1055.

52. Manion, P. D., and Griffin, D. H. 2001. Large landscape scale analysis of tree death in the Adirondack Park, New York. For. Sci. 47:542-549.

53. Manion, P. D., and Lachance, D., eds. 1992. Forest Decline Concepts. American Phytopathological Society, St. Paul, MN.

54. Manion, P. D., and Lachance, D. 1992. Forest decline concepts: An overview. Pages 181-190 in Forest Decline Concepts. P. D. Manion and D. Lachance, eds. American Phytopathological Society, St. Paul, MN.

55. Michaels, P. J., and Hayden, B. P. 1987. Modeling the climate dynamics of tree death. Bioscience 37:603-610.

56. Millers, I., Shriner, D. S., and Rizzo, D. 1989. History of hardwood decline in the Eastern United States. U. S. Dep. Agric. For. Serv. Gen. Tech. Rep. NE-126.

57. Mooney, H. A., Winner, W. E., and Pell, E. J., eds. 1991. Response of Plants to Multiple Stresses. Academic Press, San Diego, CA.

58. Morris, W. 1981. The American Heritage Dictionary of the English Language. Houghton Mifflin Co., Boston.

59. Mueller-Dombois, D. 1987. Natural dieback in forests. BioScience 37:575-583.

60. Mueller-Dombois, D. 1992. A natural dieback theory, cohort senescence as an alternative to the decline disease theory. Pages 26-37 in: Forest Decline Concepts. P. D. Manion and D. Lachance, eds. American Phytopathological Society, St. Paul, MN.

61. Mueller-Dombois, D., Canfield, J. E., Holt, R. A., and Buelow, G. P. 1983. Tree-group death in North America and Hawaiian forests: A pathological problem or a new problem for vegetation ecology? Phytocoenologia 11:117-137.

62. Newhook, F. J. 1960. Some comments on the relationship of climate to Phytophthora infection of Pinus radiata. N.Z. J. For. VIII:261-265.

63. Norris, D. M. 1979. How insects induce disease. Pages 239-255 in: Plant Disease: An Advanced Treatise. Vol. IV. J. G. Horsfall and E. B. Cowling, eds., Academic Press, New York.

64. Ostry, M. E., and Anderson, N. A. 2009. Genetics and ecology of the Entoleuca mammata-Populus pathosystem: Implications for aspen improvement and management. For. Ecol. Manage. 257:390-400.

65. Palik, B. J., Ostry, M. E., Venette, R. C., and Abdela, E. 2010. Fraxinus nigra (black ash) dieback in Minnesota: Regional variation and potential contributing factors. For. Ecol. Manage. 261:128-135. 
66. Rehfeldt, G. E., Ferguson, D. E., and Crookston, N. L. 2009. Aspen, climate, and sudden decline in western USA. For. Ecol. Manage. 258:2353-2364.

67. Schütt, P., and Cowling, E. B. 1985. Waldsterben, a general decline of forests in central Europe: Symptoms, development and possible causes. Plant Dis. 69:548-558.

68. Shields, W. J., and Bockheim, J. G. 1981. Deterioration of trembling aspen clones in the Great Lakes region. Can. J. For. Res. 11:530-537.

69. Shigo, A. L. 1986. A New Tree Biology Dictionary: Terms, Topics, and Treatments for Trees and Their Problems and Proper Care. Shigo and Trees, Assoc. Durham, NH.

70. Shurtleff, M. C., and Averre, C. W., III. 1997. Glossary of PlantPathological Terms. American Phytopathological Society, St. Paul, MN.

71. Shurtleff, M. C., Himelick, E. B., and Schoeneweiss, D. F. 1983. Report on Plant Diseases: Decline and Dieback of Trees and Shrubs. No. 641. Department of Plant Pathology, University of Illinois at UrbanaChampaign.

72. Sinclair, W. A. 1967. Decline of hardwoods: Possible causes. Proc. Int. Shade Tree Conf. 42:17-32.

73. Sinclair, W. A., and Hudler, G. W. 1988. Tree declines: Four concepts of causality. J. Arboric. 14:29-35.

74. Sinclair, W. A., and Lyon, H. H. 2005. Diseases of Trees and Shrubs, second ed. Cornell University Press, Ithaca, NY.

75. Skelly, J. M. 1992. A closer look at forest decline: A need for more accurate diagnostics. Pages 85-107 in: Forest Decline Concepts. P. D. Manion and D. Lachance, eds. American Phytopathological Society, St. Paul, MN.

76. Spaulding, P. 1909. The present status of the white-pine blights. U. S.
Dep. Agric. Bur. Plant Ind. Circ. No. 35. 12 p.

77. Spaulding, P. 1958. Diseases of foreign trees growing in the United States. U. S. Dep. Agric. Agric. Handb. 139.

78. Stephen, F. M., Salisbury, V. B., and Oliveria, F. L. 2001. Red oak borer, Enaphalodes rufulus (Coleoptera: Cerambycidae), in the Ozark Mountains of Arkansas, U.S.A.: An unexpected and remarkable forest disturbance. Integr. Pest Manage. Rev. 6:247-252.

79. Tominaga, K., Watmough, S. A., and Aherne, J. 2008. Predicting tree survival in Ontario sugar maple (Acer saccharum) forests based on crown condition. Can. J. For. Res. 38:1730-1741.

80. Waldboth, M., and Oberhuber, W. 2009. Synergistic effect of drought and chestnut blight (Cryphonectria parasitica) on growth decline of European chestnut (Castanea sativa). For. Pathol. 39:43-55.

81. Wallace, H. R. 1978. The diagnosis of plant diseases of complex etiology. Annu. Rev. Phytopathol. 16:379-402.

82. Ward, H. M. 1902. On the relations between host and parasite in the bromes and their brown rust, Puccinia dispersa (Erikss.). Ann. Bot. 16:233-315.

83. Westing, A. H. 1966. Sugar maple decline: An evaluation. Econ. Bot. 20:196-212.

84. Wood, D., Yanai, R., Allen, D., and Wilmot, S. 2009. Sugar maple decline after defoliation by forest tent caterpillar. J. For. 29-37.

85. Woodward. S., Stenlid, J., Karjalainen, R., and Huttermann, A. 1998. Heterobasidion annosum: Biology, Ecology, Impact, and Control. CAB International, New York.

86. Worrall, J. J., Egeland, L., Eager, T., Mask, R. A., Johnson, E. W., Kemp, P. A., and Shepperd, W. D. 2008. Rapid mortality of Populus tremuloides in southwestern Colorado, USA. For. Ecol. Manage. 255:686-696. 